\title{
A Retrospective Study of Patients with Pemphigus during a Five-year Period, 1988-1992, in the Dr. Cipto Mangunkusumo Hospital, Jakarta
}

\author{
A.A.A.Made Citrarasmi, Adhi Djuanda
}

\begin{abstract}
Abstrak
Telah dilakukan penelitian retrospektifpara penderita pemfigus selama 5 tahun (1988 - 1992 ). Diagnosis berdasarkan anamnesis, gambaran klinis, pemeriksaan histopatologik, dan imunofluoresensi. Selama itu terdapat 26 kasus pemfigus terdiri atas 19 wanita dan 7 pria, berumur antara 14 sampai 78 tahun. Jenis pemfigus ialah pemfigus vulgaris $10 \mathrm{kasus,} \mathrm{pemfigusfoliaseus} 12 \mathrm{kasus,} \mathrm{dan} \mathrm{pemfigus}$ eritematosus 4 kasus. Lama penyakit antara 1 bulan hingga 2 tahun, lama rawat-inap antara 5 hari sampai 5 bulan. Pengobatan yang utama ialah kortikosteroid, dosis awal deksametason antara 15 sampai $20 \mathrm{mg}$ dan prednison antara 30 sampai $80 \mathrm{mg}$. Terdapat 2 kasus pemfigus vulgaris dan 3 kasus pemfigus foliaseus yang meninggal, yaitu 4 kasus disebabkan oleh bronkopneumonia dan 1 kasus karena septikemia.
\end{abstract}

\begin{abstract}
A retrospective study of pemphigus cases during a five-year period, from 1988 to 1992, was performed. The diagnosis was based on history, clinical picture, histopathological finding, and immunofluorescence examination. During a five-year period there were 26 cases of pemphigus, consisting of 19 females and 7 males, their ages varied from 14 to 78 years. The following types were recognized: pemphigus vulgaris in 10 cases, pemphigus foliaceus in 12 cases, and pemphigus erythematosus in 4 cases. The duration of illness was between 1 month to 2 years, the average hospitalization ranging from 5 days to 5 months. The main therapy was corticosteroids with an initial dose of dexamethasone between 15 to $20 \mathrm{mg}$ and prednisone with maximal dose $80 \mathrm{mg}$ daily. Two cases of pemphigus vulgaris and 3 cases of pemphigus foliaceous was died, due to bronchopneumonia in 4 cases and septicaemia in 1 case.
\end{abstract}

Keywords : Pemphigus, Incidence

\section{INTRODUCTION}

Pemphigus refers to a group of autoimmune intraepidermal blistering diseases of the skin and mucous membranes, ${ }^{1}$ and is not related to sex. ${ }^{2}$ Jews are probably more frequently affected. Pemphigus usually affects people between the age of $30-60$ years, but it can also occur in childhood and older age. ${ }^{2}$

Based primarily on the level of blister formation, the pemphigus group may be subdivided into superficial and deep forms. ${ }^{3}$ Types of pemphigus are pemphigus vulgaris, pemphigus foliaceus, pemphigus erythematosus, and pemphigus vegetans.

The major histologic feature of all variants is acantholysis, the disruption of normal cell-to-cell adhesion, which leads to intraepidermal blister formation. ${ }^{1}$
Most patients with pemphigus demonstrate IgG autoantibodies directed against an antigen located on the surface of keratinocytes. ${ }^{1}$

Although the stimulus for autoantibody production is unknown, several mechanisms have been proposed to explain the pathogenesis of acantholysis. First pemphigus antibodies induce acantholysis through local stimulation of the plasminogen-plasmin system, second pemphigus antibodies fix complement and thereby alter cell membrane integrity to produce acantholysis. ${ }^{1}$

The first choice for treatment is corticosteroids, ${ }^{1,3,4,5}$ other treatments are immunosuppressive drugs, gold therapy, and plasmapheresis. ${ }^{1}$ Before the usage of corticosteroids the rate of death was $50 \%{ }^{6}$ Death occurs in the acute disease after a few months, or after several years of intermittent course, due to 
secondary complications such as septicemia, bronchopneumonia, electrolyte imbalance, and cachexia. ${ }^{2,3,6}$

Reporting cases of pemphigus is important to know the incidence rate, the types of pemphigus, the result of treatment, its mortality rate, and the cause of death.

\section{MATERIAL AND METHOD}

The records of all patients with pemphigus admitted to our department during a 5 year-period, from January 1, 1988 to December 31, 1992 were collected and studied.

\section{RESULT}

A retrospective study of pemphigus patients who were hospitalized in the Dr Cipto Mangunkusumo Hospital, during a 5-year period, 1988-1992, is shown in Table 1. There were 26 cases of pemphigus, consisting of 19 females and 7 males (Table 2). The ages varied from 14 to 78 years (Table 3 ). The pemphigus vulgaris patients varied in age from 16 to 69 years, pemphigus foliaceus from 14 to 78 years, whereas pemphigus erythemato-sus from 30 to 75 years (Table 1).

The duration of disease ranged from 1 month to 3 years. Patients were hospitalized between 5 days to 5 months.

The types of pemphigus consisted of pemphigus vulgaris in 10 cases, pemphigus foliaceus in 12 cases, and pemphigus erythematosus in 4 cases (Table 1).

The subjective sign of pemphigus vulgaris was itching in 3 cases $(11,5 \%)$. The general condition was good in 5 cases $(19.2 \%)$, moderate in 1 case $(3.8 \%)$, poor in 3 cases $(11.5 \%)$, and apathy in 1 case $(3.8 \%)$. Pemphigus foliaceus with good general condition was seen in 2 cases $(7.7 \%)$, moderate in 3 case $(11.5 \%)$, and poor in 7 cases (26.9\%). Good general condition in pemphigus erythematosus patients was observed in 2 cases $(7.7 \%)$, moderate in 1 case $(3.8 \%)$, and poor in 1 case $(3.8 \%)$ (Table 4$)$.

Among 26 cases of pemphigus, 26 had accompanying diseases, such as pulmonary tuberculosis in 5 cases, pleuropneumonia in 2 cases, bronchit is in 1 case, spontaneus pneumothorax in 1 case, heart arrythmia in 2 cases, bronchiectasis in 2 cases, hypertension in 3 cases, heart failure with sinus tachycardia in 2 cases, angina pectoris, insomnia, myringitis and external otitis, thrombocytopenia without DIC, hematemesis and melena due to erosive gastritis, thoraco- lumbal osteoporosis, pelvis and first lumbar compresion fracture, renal insufficiency due to acute glomerulonephritis, normochromic normocytic anemia, gangrene of the pulp and posttotal laryngectomia due to squamous cell carcinoma of the pharynx respectively in one case (Table 5). There was a possibility that a patient also suffered from more than one disease.

Complications of pemphigus were blepharoconjunctivitis in 3 cases, conjunctivitis in 5 cases, bronchopneumonia in 4 cases, acute pharyngitis and septicemia in 2 cases, rhinopharyngitis and foetor ex ore in 1 case (Table 1).

Among the 26 cases, a histopathologic examination was performed in 21 cases. The result were as follows : 8 cases confirmed the diagnosis of pemphigus vulgaris, 9 pemphigus foliaceus, and 4 pemphigus erythematosus. Histopathologic examination was not performed in the remaining 5 cases since they had received corticosteroids prior to hospitalization.

Direct immunofluorescence which detects immunoglobulins (mainly IgG) and complement components such as C3 within the epidermal tissue of the blister and its margin, was performed in 17 patients. Only 4 cases were in conformity with pemphigus (Table 1). In 9 cases the examination was not performed.

All patients were treated with corticosteroids only, 9 patients with dexamethasone, while 17 patients with prednisone. The initial dose of dexamethasone was 15 to $20 \mathrm{mg} /$ day, whereas prednisone 30 to 80 $\mathrm{mg} /$ day. After clinical healing the dose was tapered off.

The side effects l candidosis, vulvovaginitis, fluid retention, and Cushing syndrome respectively in one case (Table 1).

The outcome of the patients was as follows: 5 cases died $(21.7 \%)$, consisting of 2 cases of pemphigus vulgaris and 3 cases cases of pemphigus foliaceus. The cause of death was bronchopneumonia in 4 cases and septicemia in 1 case (Table 1 ).

\section{DISCUSSION}

Pemphigus is a rare disease, Jews are probably more frequently affected, ${ }^{2}$ it is not related to sex. ${ }^{2,1}$ In this study females were more frequently affected than males $(80,8 \%$ of all the cases). The incidence varied from 0.5 to 3.2 cases per 100.000 population per year. The most frequent type of pemphigus was pemphigus vulgaris, followed by pemphigus foliaceus and pemphigus erythematosus. ${ }^{1,2,3}$ While in this study pemphigus foliaceus was the most frequent type followed by pemphigus vulgaris and pemphigus erythematosus, whereas no case of pemphigus vegetans was encountered.

Pemphigus can also affect all ages, including children. ${ }^{1,6,7}$ Pemphigus vulgaris is generally seen in patients in the fifth or sixth decade, ${ }^{2}$ pemphigus 
foliaceus in the fourth or fifth decade ${ }^{3}$ or $30-60$ years old. ${ }^{2}$ In this study a different finding was noticed, pemphigus vulgaris occurred in 16 - 69 years of age, pemphigus foliaceus in 14-78 years, whereas pemphigus erythematosus in $30-75$ years.

Subjective itching is uncommon in pemphigus vulgaris, painful erosions was the dominant clinical feature. ${ }^{2,3,7}$ Itching was dominant in only 3 of our cases.

Duration of the disease in this study ranged from 1 month to 3 years. Nine cases were hospitalized more than once. This showed that pemphigus is a chronic disease as mentioned in the literature.

The initial disease in pemphigus vulgaris is in the mouth. ${ }^{1,3}$ Among our cases foetor ex ore was only found in 1 case $(3.8 \%)$ (Table 1 ).

The lesions of pemphigus foliaceus often develop initially on the face, scalp, chest, or back and may spread to involve large areas of the skin, presenting as generalized exfoliative dermatitis, and oral lesions are not frequently present. ${ }^{3}$ Oral lesion as superficial erosive stomatitis was only found in 1 case in our study.

The eyes can also be affected as pyogenic conjunctivitis. ${ }^{1,2}$ In this study 3 cases with blepharoconjunctivitis and 5 cases with conjunctivitis were found. Other mucous membranes, including oropharyngeal pharyngeal, laryngeal, and nasal can be affected, ${ }^{3,6}$ which was only found in 1 case in this study.

The first choice of treatment in pemphigus is corticosteroids as was done in all of our cases. The dose of prednisone depends on the grade of the disease. In severe cases the suggested dose is $60-150 \mathrm{mg}$ per day, or $3 \mathrm{mg} /$ body weight. ${ }^{4}$ If a very high dose will be given we prefer dexamethasone injection intramuscularly or intravenously instead of prednisone because it is more practical. For either pemphigus foliaceus or pemphigus erythematosus, the dose was not as high as for pemphigus vulgaris, only $60 \mathrm{mg} /$ day prednisone or another corticosteroid with an equivalent dose. ${ }^{4,5}$ In our cases, 10 cases were treated with dexamethasone, with an initial dose ranging from 15 to $20 \mathrm{mg}, 16$ cases were treated with prednisone varying from 30 to $80 \mathrm{mg}$ daily.
Besides corticosteroids we gave also antibiotic to prevent secondary infection and ACTH (synacthen depot), which was given every week, with a dose of 2 mg weekly to prevent atrophy of the adrenal cortex. ${ }^{4}$ We only used corticosteroids and was not combined with cytostatics because we were afraid of the side effects.

The side effects of corticosteroids are depression of the immunity and prone to infection. In our cases, side effects found were herpes zoster, steroid acneiform eruption, oral candidosis, vaginal candidosis each in one case, and active pulmonary tuberculosis in 2 cases. Another side effect was steroid diabeticum in 4 cases.

Corticosteroids also cause electrolyte imbalances and sodium retention, two cases with fluid retention were found in this study.

The cause of death of pemphigus is septicemia, bronchopneumonia, cachexia, ${ }^{2,3,5}$ and fluid imbalance. $^{6}$ The mortality rate is $60-90 \%{ }^{1,4}$ This is in accordance with our study, 2 cases of pemphigus vulgaris $(8,7 \%)$, and 3 cases pemphigus foliaseus (13\%) died, i.e. 4 cases due to bronchopneumonia and 1 case due to septicemia.

\section{REFERENCES}

1. Korman N, Cleveland OH. Pemphigus. Arch Dermatol $1988 ; 18(6): 1219-83$.

2. Braun Falco, Plewig G, Wolft HH, Winkelmann RK. Dermatology. 3rd ed. Berlin : Springer-Verlag, 1991: 467-501.

3. Jordon RE. Pemphigus. In : Fitzpatrick TB, Eisen AZ, Wolff K, Freedberg IM, Austen KF. Dermatology in general medecine, 3rd. New York : Mc Graw Hill, 1987 : 571 - 8.

4. Djuanda A. Pemphigus. Majalah Kedokteran Indonesia $1973 ; 11 / 12: 204-7$

5. Djuanda A. Dermatosis eritroskuamosa. In : Djuanda A, ed. Ilmu Penyakit Kulit dan Kelamin, 1st ed. Jakarta : Medical University of Indonesia, $1987: 153$ - 63.

6. Provost TT, Zone JJ. Bullous Disease. In : Moschella SL, Hurley HJ. Dermatology, 2nd ed. Philadelphia : WB Saunders, 1975 : 557-66.

7. Arnold HL, Odom RB, James WD. Andrew's Diseases of the skin, 8th ed. Philadelphia : WB Saunders, 1990 : 534-43. 


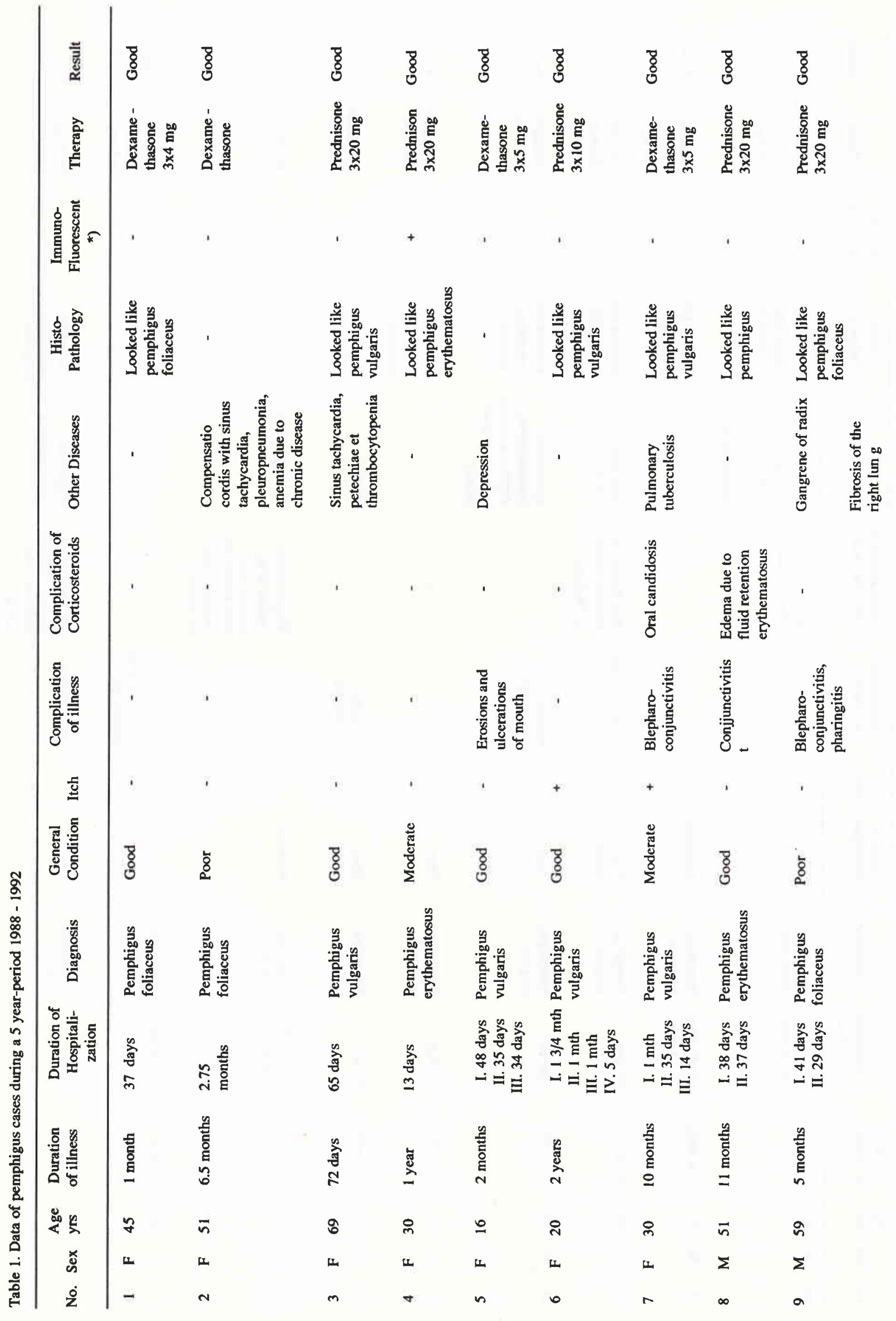




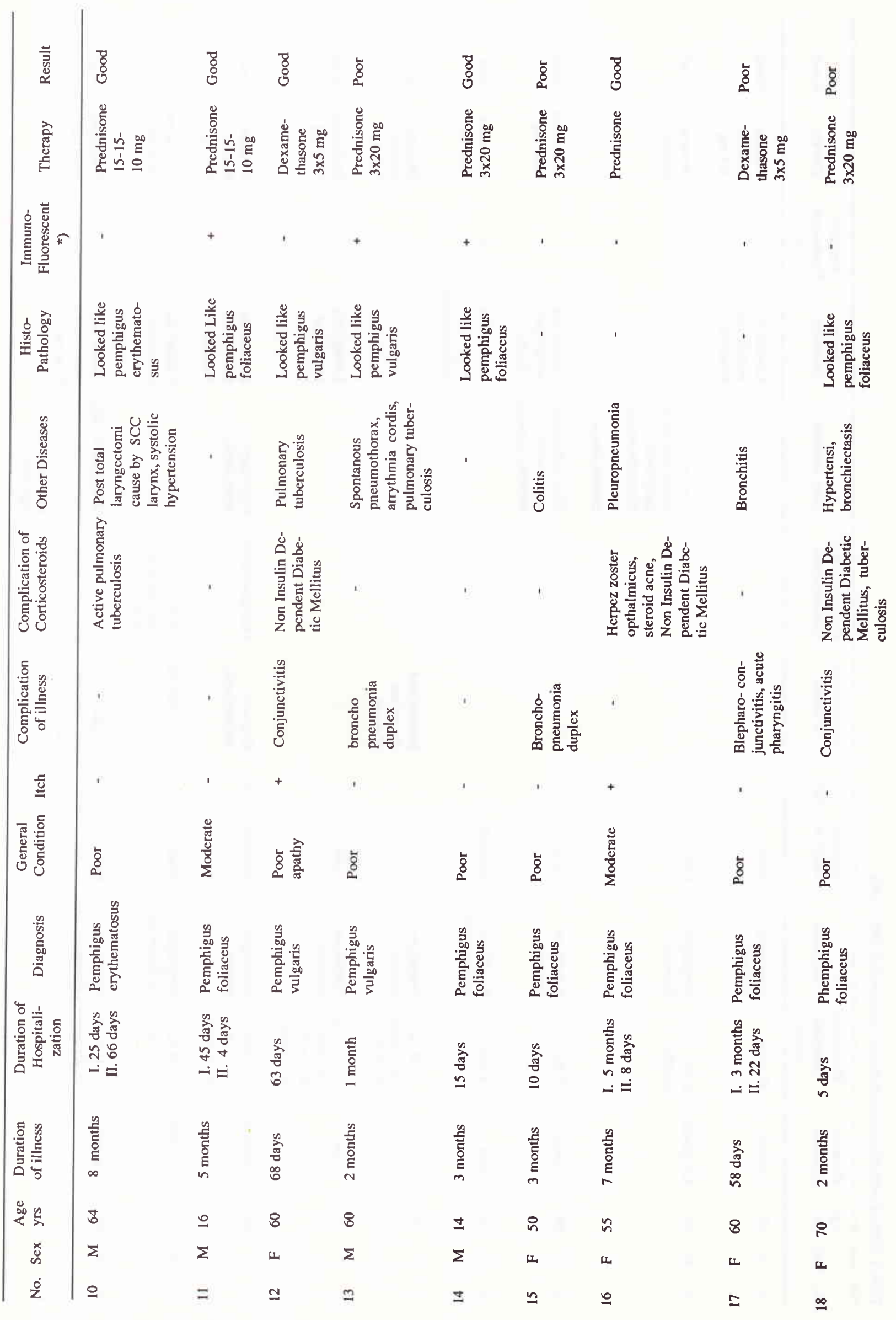




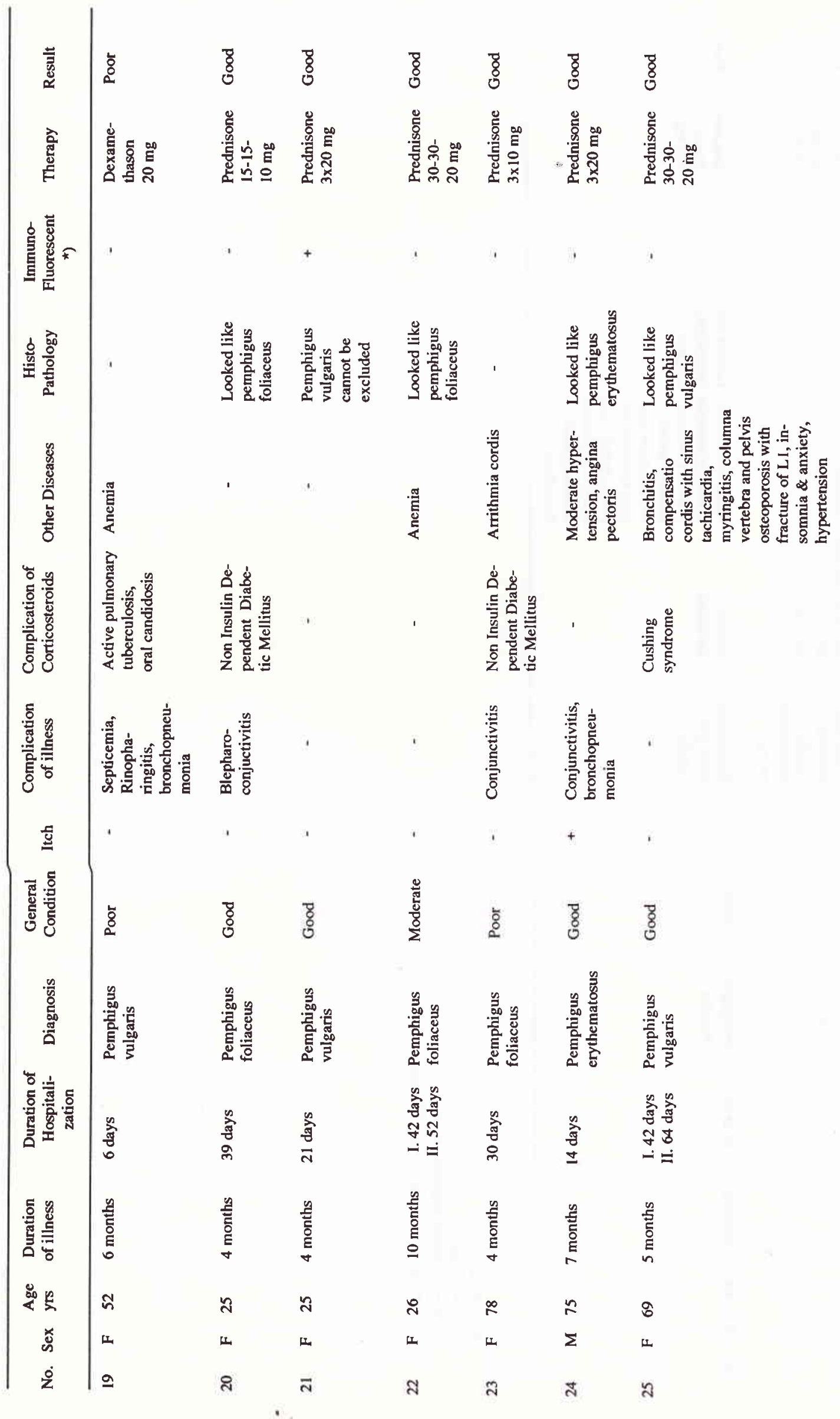




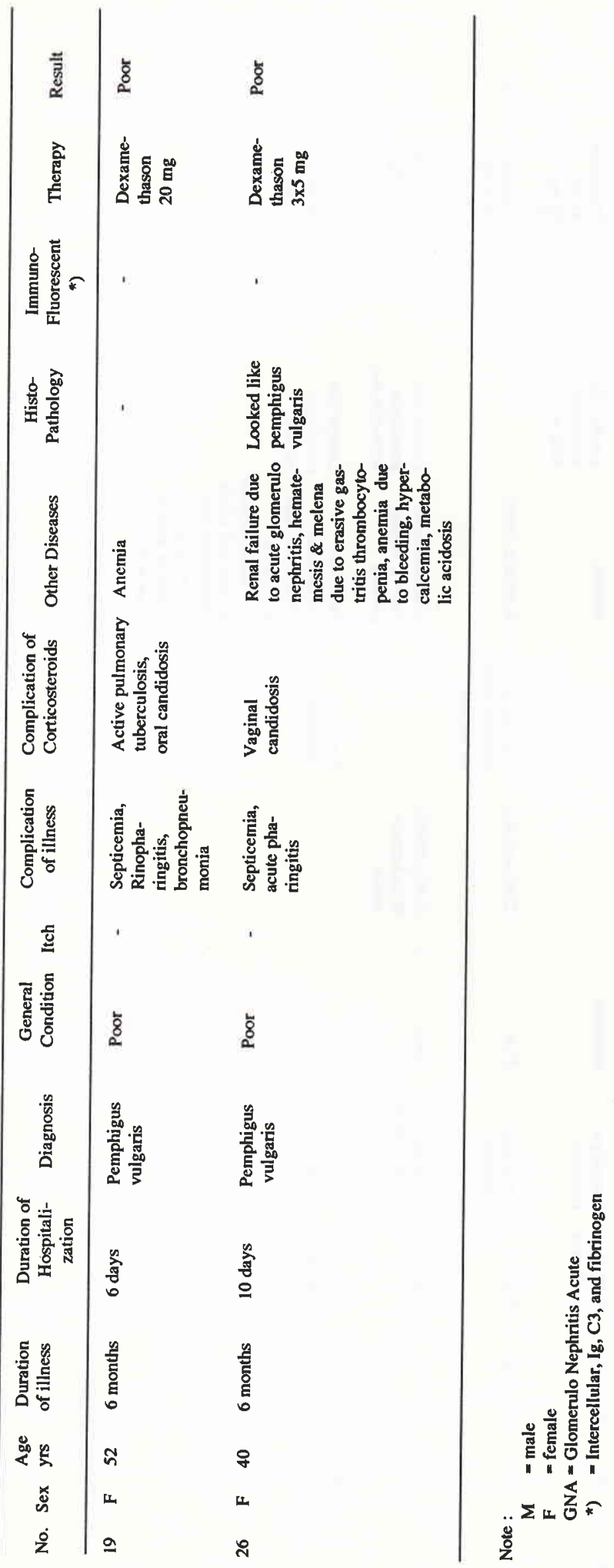


Table 2. Sex distribution of pemphigus cases

\begin{tabular}{lcccccc}
\hline \multirow{2}{*}{ Sex } & \multicolumn{3}{c}{ Type of pemphigus } & Total & $\%$ \\
\cline { 2 - 5 } & $\begin{array}{c}\text { Pemphigus } \\
\text { vulgaris }\end{array}$ & $\begin{array}{c}\text { Pemphigus } \\
\text { foliaceus }\end{array}$ & $\begin{array}{c}\text { Pemphigus } \\
\text { erythematosus }\end{array}$ & \\
\hline Female & 8 & 10 & 1 & 19 & 73,1 \\
Male & 2 & 2 & 3 & 7 & 26,9 \\
\hline
\end{tabular}

Table 3. Age distribution of pemphigus cases

\begin{tabular}{|c|c|c|c|c|c|}
\hline \multirow{2}{*}{ Age } & \multicolumn{3}{|c|}{ Type of pemphigus } & \multirow{2}{*}{ Total } & \multirow{2}{*}{$\%$} \\
\hline & $\begin{array}{c}\text { Pemphigus } \\
\text { vulgaris }\end{array}$ & $\begin{array}{l}\text { Pemphigus } \\
\text { foliaceus }\end{array}$ & $\begin{array}{l}\text { Pemphigus } \\
\text { erythematosus }\end{array}$ & & \\
\hline-14 & - & 1 & - & 1 & 3,8 \\
\hline $15-22$ & 2 & 1 & - & 3 & 11,5 \\
\hline $23-30$ & 2 & 2 & 1 & 5 & 19,2 \\
\hline $31-38$ & - & - & - & - & - \\
\hline $39-46$ & - & 1 & - & 1 & 7,6 \\
\hline $47-54$ & 1 & 2 & 1 & 4 & 15,4 \\
\hline $55-62$ & 2 & 3 & - & 5 & 19,2 \\
\hline $63-70$ & 1 & 1 & 1 & 3 & 15,4 \\
\hline$>71$ & - & 1 & - & 1 & 7,6 \\
\hline
\end{tabular}

Table 4. General condition distribution of pemphigus cases

\begin{tabular}{lccccc}
\hline $\begin{array}{l}\text { General } \\
\text { condition }\end{array}$ & \multicolumn{3}{c}{ Type of pemphigus } & Total & $\%$ \\
\cline { 2 - 4 } & $\begin{array}{c}\text { Pemphigus } \\
\text { vulgaris }\end{array}$ & $\begin{array}{c}\text { Pemphigus } \\
\text { foliaceus }\end{array}$ & $\begin{array}{c}\text { Pemphigus } \\
\text { erythematosus }\end{array}$ & & \\
\hline Good & 5 & 2 & 3 & 10 & 38,5 \\
Moderate & 1 & 3 & 1 & 5 & 19.2 \\
Poor & 3 & 7 & - & 10 & 38,5 \\
Apathy & 1 & - & - & 1 & 3,8 \\
\hline
\end{tabular}

